\title{
Effect of Fertilization and Weed Management on Weed Flora of Hemp Crop
}

\author{
Angeliki KOUSTA, Panayiota PAPASTYLIANOU*, Nikolina CHEIMONA, Ilias TRAVLOS, Ioanna \\ KAKABOUKI, Dimitrios BILALIS
}

Agricultural University of Athens, School of Plant Sciences, Department of Crop Science, Laboratory of Agronomy, 75 Iera Odos St., 11855 Athens, Greece.

*corresponding author: ppapastyl@aua.gr

BulletinUASVM Horticulture 77(2) / 2020

Print ISSN 1843-5254, Electronic ISSN 1843-5394

DOI:10.15835/buasvmcn-hort: 2020.0013

\begin{abstract}
Hemp is known to have a competitive advantage over weeds. Despite its suppressive ability, weed infestation remains an important issue during the early growth of the crop. The aim of this study was to determine the effect of fertilization and weed management on weed flora and hemp growth parameters during initial growth in the 2019 season. The experiment was laid out in a split-split plot design with three replicates: three hemp cultivars as main plots, three fertilization treatments as sub-plots and two sub-sub-plots (weedy, weed free). For the computation of height and biomass weight, 10 plants were randomly selected in each plot. Weed species were collected by quadrate and density and biomass weight were determined. ANOVA revealed that all factors and their interactions significantly affected plant traits. Hemp cultivars showed different competitive ability. 'Futura 17' reduced weed measurement traits better than 'Uso 31'. Density and biomass of nitrophilous weeds increased with the higher $\mathrm{N}$ dose compared to control (up to $56 \%$ and $79 \%$ respectively), therefore negatively affecting the growth of the hemp plants. Further research is needed in order to identify useful information on interactions between weeds and hemp crop to address potential yield losses under different weed management systems.
\end{abstract}

Keywords: Cannabis sativa L., cultivars, fertilization, weed density, weed species

\section{Introduction}

Hemp (Cannabis sativa L.) an annual, herbaceous crop of Asian origin, is considered as one of the oldest crops used by man for a wide range of products. Once a major fiber crop in Europe, hemp cultivation declined at the end of the $19^{\text {th }}$ century mainly due to the competition from other increasingly profitable feedstocks such as cotton and synthetic fibers (Struik et al., 2000). Nowadays, the qualification of hemp as a multipurpose crop has induced a renewed interest globally, with cultivation on approximately 73.727 ha in more than 47 countries (FAOSTAT,
2018). In most regions of the European Union, its cultivation has been reauthorized and the crop area is estimated at around 33.000 ha (Carus, 2017). In Greece there is an upward trend in hemp cultivation and the harvested area is estimated at 385 ha, mainly for the production of CBD or seed oil creating new opportunities in the market for industrial and, prospectively, medical cannabis products (Bilalis et al., 2019). The versatility of hemp lends itself to the development of numerous products as all above ground and underground parts of plant are exploitable. In fact, hemp is a multi-use, multi-functional crop that provides 
raw material to a large number of traditional and innovative industrial applications such as textiles, food, papermaking, construction materials, cosmetics and pharmaceutical products. The global market for hemp is estimated at more than 25,000 products (Salentjin et al., 2015).

Hemp can be grown in a wide range of agroecological conditions and management practices. In fact, it has been promoted as a high-yielding crop with low input cultivation techniques (Amaducci et al., 2015). However, experimental results confirm that hemp requires special attention to nutrition needs, especially nitrogen fertilization. Nitrogen has proved the major nutrient needed to positively influence crop productivity and plant quality characteristics (Aubin et al., 2015; Papastylianou et al., 2017; Deng et al., 2019). On the other hand, nitrogen fertilization not only affects crop development and yield, but also weed establishment and growth, as many weeds have high nitrogen demands (Blackshaw et al., 2003, Travlos et al., 2019). Hemp is well known as an effective weed-suppressing crop that has a very important position in crop rotations, increasing the yield of the subsequent crop. This ability is mainly attributed to its high competitiveness for water, nutrients and light due to its fast growth rate and canopy closure which over-shadows the soil quickly after the initial growth phase (Hall et al., 2014; Amaducci et al., 2015). In addition, the crop produces allelochemicals that suppress growth and establishment of other plants (Pudelco et al., 2014). As a result, the opinion that weed control in hemp is usually unnecessary, specially under high crop densities, has been expressed by a number of researchers (Struik et al., 2000; Amaducci et al., 2015; Campiglia et al., 2017). However, other studies suggest that weed control is essential for high crop yields when hemp is grown for seed or at low plant densities (Jankauskiené et al., 2014; Flessner et al., 2019). Although these latter studies provide indication that weed infestation in early crop growth can cause severe yield losses in hemp, information on crop interaction with weed communities of local agro-ecosystems under different types of cultural management is very scarce (Sandler and Gibson, 2019). Therefore, the aim of this study was to investigate the effect of different fertilization rates and weed management on weed flora and crop growth parameters during the initial growth phase.

\section{Materials and Methods}

A field experiment was carried out at the Agricultural University farm located in Athens (southern Greece: latitude $37^{\circ} 58^{\prime} \mathrm{N}$, longitude $23^{\circ} 32^{\prime} \mathrm{E}$, altitude $30 \mathrm{~m}$ above sea level) during the 2019 growing season. The soil was clay loam (29.3\% clay, $33.8 \%$ silt and $36.9 \%$ sand) with $\mathrm{pH} 7.17$, nitrate-nitrogen $\left(\mathrm{NO}_{3}-\mathrm{N}\right) 12.4 \mathrm{mg} \mathrm{kg}^{-1}$ soil, available phosphorus (P) $13.2 \mathrm{mg} \mathrm{kg}^{-1}$ soil, available potassium (K) $201 \mathrm{mg} \mathrm{kg}^{-1}$ soil and $1.17 \%$ organic matter. The site was managed according to organic agriculture guidelines (EC 834/2007). Weather data (rainfall, maximum and minimum air temperatures) were recorded daily and are reported as mean monthly data for the period in which the study was conducted (Tab. 1). The mean air temperature and rainfall showed no significant differences during the growing period of June to August. Total rainfall during the experimental period was $5.8 \mathrm{~mm}$. These variations are typical for the Mediterranean climate, which is characterized by a long, hot and dry summer during which full irrigation is essential for growing crops.

Table 1. Monthly means of maximum $\left(\mathrm{T}_{\max }\right)$, minimum $\left(\mathrm{T}_{\text {min }}\right)$ and average $\left(\mathrm{T}_{\text {average }}\right)$ air temperatures $\left({ }^{\circ} \mathrm{C}\right)$ and total rainfall $(\mathrm{mm})$ in the experimental site for 2019 growing season

\begin{tabular}{ccccc}
\hline Month & $\mathrm{T}_{\max }\left({ }^{\circ} \mathrm{C}\right)$ & $\mathrm{T}_{\min }\left({ }^{\circ} \mathrm{C}\right)$ & $\mathrm{T}_{\text {average }}\left({ }^{\circ} \mathrm{C}\right)$ & $\begin{array}{c}\text { Rainfall } \\
(\mathrm{mm})\end{array}$ \\
\hline May & 24.2 & 15.8 & 19.9 & 2.2 \\
\hline June & 31.0 & 22.7 & 26.8 & 2.6 \\
\hline July & 32.3 & 23.8 & 28.2 & 1.0 \\
\hline August & 33.6 & 25.6 & 29.3 & 0 \\
\hline
\end{tabular}

The experimental design was split-split plot, with three European hemp cultivars characterized by different origin and maturity group (Tab. 2) as the main plots, fertilization treatments as the subplots and weed management as the sub-sub plots in a randomized complete block design replicated three times. The fertilizer treatments consisted of three $\mathrm{N}$ rates [control (N0), $70 \mathrm{~kg} \mathrm{ha}^{-1}$ (N1), and $140 \mathrm{~kg} \mathrm{ha}^{-1}$ (N2)]. To obtain three levels of initial availability equal to the rates mentioned above, nitrogen was distributed as organic fertilizer 7-47 before sowing. The crop was kept free of weeds in the hand-hoeing plots while the rest did not accept any weed management (WF: weed free 
and W: weedy, respectively). The plot size of each fertilization treatment was $10 \mathrm{~m} \times 7.2 \mathrm{~m}$ and the experimental plots were $2.4 \mathrm{~m} \times 5 \mathrm{~m}$ and consisted of 8 rows $0.30 \mathrm{~m}$ apart. Seeds were hand-planted at $3 \mathrm{~cm}$ depth on 31 May 2019 in order to achieve the planned crop density of 65-70 plants $\mathrm{m}^{-2}$ with wheat (Triticum turgidum subsp. durum L.) as the preceding crop. A drip irrigation system was installed in the experimental plots, watering when necessary.

Table 2. Origin, sexual type and maturity group of the hemp cultivars used in the research (seed showed a legal THC content i.e. $<0.2 \% \mathrm{w} / \mathrm{v}$ )

\begin{tabular}{cccc}
\hline Cultivar & Origin & Sexual type & $\begin{array}{c}\text { Maturity } \\
\text { group }\end{array}$ \\
\hline 'Uso 31' & Germany & Monoecious & Early \\
\hline 'Fedora 17' & France & Monoecious & Medium \\
\hline 'Futura 75' & France & Monoecious & Late \\
\hline
\end{tabular}

For the determination of plant height and above-ground biomass dry weight (51 DAS), 10 plants were randomly selected from the middle rows of the experimental plots. Dry weight was determined after drying for 48 hours at $65^{\circ} \mathrm{C}$ until their weight remained constant. Data pertaining to weed population and dry matter were also recorded. Weeds were sampled from three 0.5 $\mathrm{m}^{-2}$ quadrate placed on the diagonal of each experimental plot. Above-ground weed biomass was collected, identified and counted, then ovendried at $65^{\circ} \mathrm{C}$ to a constant weight to record weed dry weight. Values obtained (means of three qua- drates) were transformed per area unit for density (numbers $\mathrm{m}^{-2}$ ) and for biomass $\left(\mathrm{g} \mathrm{m}^{-2}\right.$ ).

For the statistical analysis SigmaPlot 12 statistical software (Systat Software Inc., San Jose, CA, USA) was used. Values were compared by analysis of variance (ANOVA) and Fisher's protected least significant difference at $5 \%$ level of probability (LSD 0.05) was used to compare the main effect and interaction means.

\section{Results and Discussion}

Weeds were classified, according to their biological cycle and leaf morphology. Four of the identified weed species were annuals and five perennials (Tab. 3). Among the annual weeds, the most frequent species was Echinochloa crus-galli, followed by Portulaca oleracea and Amaranthus retroflexus (43\%, 30\% and 23\%, respectively). Solanum elaeagnifolium was the dominant species among the perennials, while Malva sylvestris and Convolvulus arvensis had a lower presence (81\%, $11 \%$ and $4 \%$ respectively) (Fig. $1 \mathrm{a}$ and $\mathrm{b}$ ).

The combined analysis of variance revealed that plant height and dry biomass were significantly affected by the competing hemp cultivars, the fertilization treatments and the weed management $(P<0.001)$. Moreover, the interaction terms between the above-mentioned factors were also significant $(P<0.001)$. In particular, it was observed that the maximum plant height and biomass values were recorded at the $140 \mathrm{~N}$ application rate in the weed-free plots. Weed management had a significant impact on the measurement characteristics. Weeds competed with crop plants for nutrients, water, sunlight and space and thus reduced plant growth. Plant

Table 3. Classification of weeds in the experiment

\begin{tabular}{lccc}
\hline \multicolumn{1}{c}{ Weed species } & Family name & Biological cycle & Leaf morphology \\
\hline Amaranthus retroflexus & Amaranthaceae & Annual & Broad-leaf \\
\hline Convolvulus arvensis & Convolvulaceae & Perennial & Broad-leaf \\
\hline Cyperus rotundus & Cyperaceae & Perennial & Narrow-leaf \\
\hline Datura stramonium & Solanaceae & Perennial & Broad-leaf \\
\hline Echinochloa crus-galli & Poaceae & Annual & Narrow-leaf \\
\hline Malva sylvestris & Malvaceae & Perennial & Broad-leaf \\
\hline Portulaca oleracea & Portulacaceae & Annual & Broad-leaf \\
\hline Solanum elaeagnifolium & Solanaceae & Perennial & Broad-leaf \\
\hline Tribulus terrestris & Zygophylaceae & Annual & Broad-leaf \\
\hline
\end{tabular}




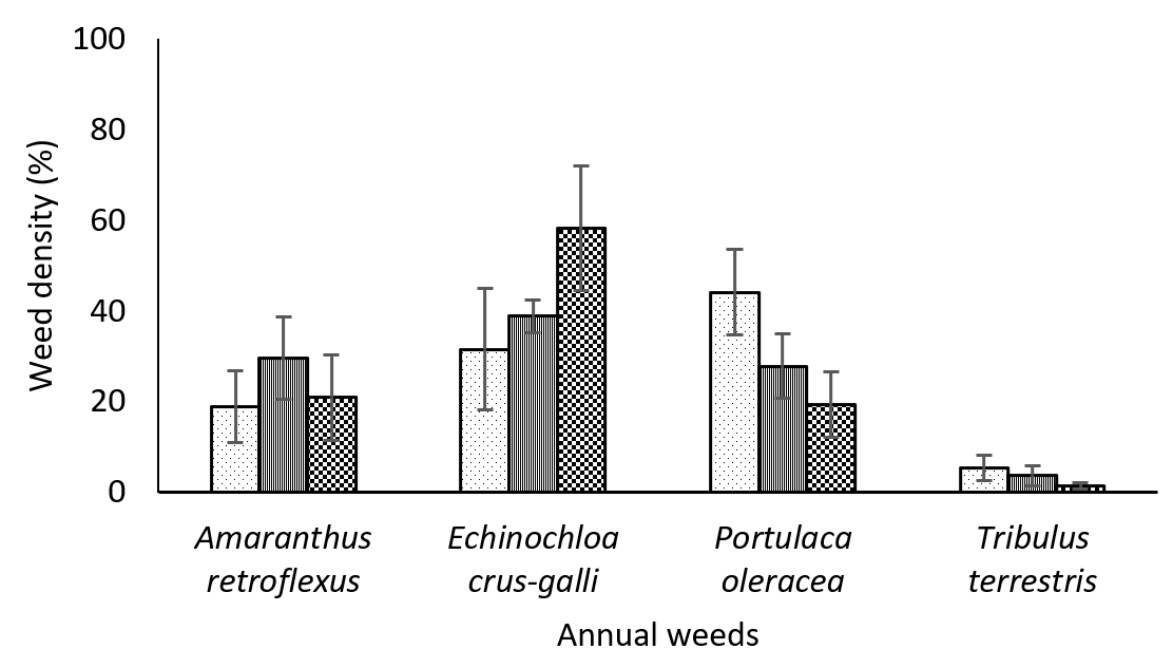

a

$\square$ USO $31 \square$ FEDORA 17 MFUTURA 75

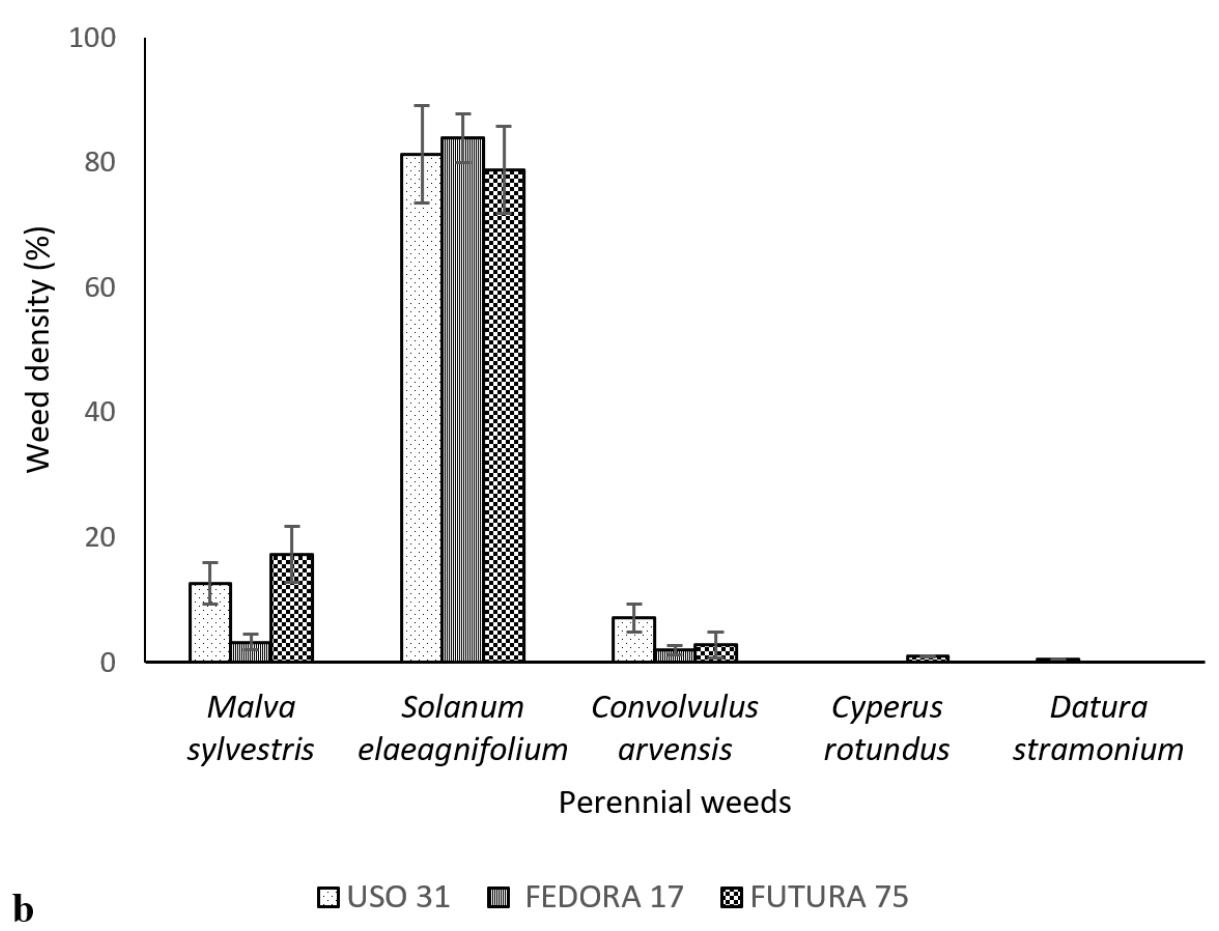

Figure 1. Density of annual (a) and perennial weeds (b) at 51 days after sowing of hemp crop. Vertical bars indicate the standard errors of the means.

height and biomass decreased by $23 \%$ and $49 \%$ respectively in the presence of weeds regardless of fertilization rates and cultivars. Lower biomass was obtained from the early flowering cultivar 'Uso 31 ', while the highest plant growth and biomass were observed in the cultivar 'Futura 75' under all fertilizer rates and weed management treatments (Fig. 2a and b). Comparable results were reported by Campiglia et al. (2017), Papastylianou et al.,
(2017) and Tang et al., (2016) who found that high $\mathrm{N}$ fertilization had a positive impact on hemp biomass. In addition, as reported by other studies, cultivars 'Futura 75' and 'Fedora 17' showed higher biomass yield and weed competitiveness compared to the early cultivar 'Uso 31 ' under contrasting environments and management practices (Sausserde et al., 2013; Jankauskiené et al., 2014; Tang et al., 2016). 

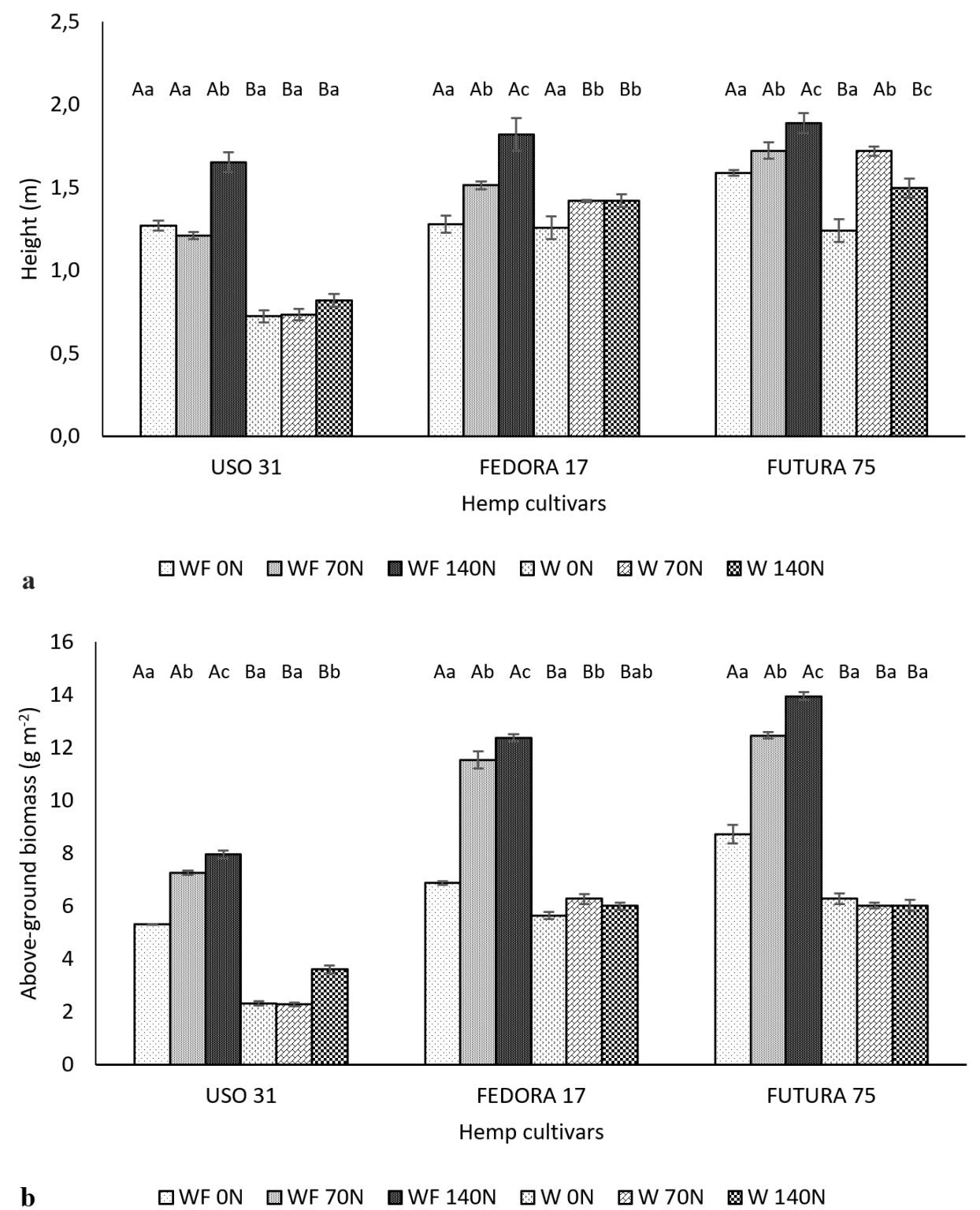

Figure 2. Height (a) and above-ground biomass (b) of hemp cultivars under different fertilization rates and weed management treatments [control $\left.(0 \mathrm{~N}), 70 \mathrm{~kg} \mathrm{ha}^{-1}(70 \mathrm{~N}), 140 \mathrm{~kg} \mathrm{ha}^{-1}(140 \mathrm{~N})\right]$, (WF: weed free and W: weedy)

Different capital letters denote significant differences between weed management treatments under the same fertilization rate $(P<0.05)$. Different lowercase letters denote significant differences between fertilization rates under the same weed management treatment $(P<0.05)$. Vertical bars indicate the standard errors of the means.

The combined analysis of variance revealed that weed density and dry biomass were in most cases significantly affected by the fertilization treatments and the weed management. In addition, the interaction terms between cultivar by fertilization and fertilization by weed manage- ment were also significant. The average density and biomass of weeds in our study was relatively high, especially in the case of cultivar 'Uso 31' (281 plants $\mathrm{m}^{-2}$ and $180 \mathrm{~g} \mathrm{~m}^{-2}$ ), while 'Fedora 17' and 'Futura 75' showed similar values (220 and 233 plants $\mathrm{m}^{-2}$ and 111 and $118 \mathrm{~g} \mathrm{~m}^{-2}$ respectively). Comparable results were reported by Jankauskiené et al., (2014) and Campiglia et al., (2017) who found the highest weed density and above-ground biomass in the plots of the early and short cultivar 'Uso 31'and lower values for "Futura 75'. Weed density was increased after the application of $140 \mathrm{~kg} \mathrm{~N} \mathrm{ha}^{-1}$ compared to unfertilized control. In 
Table 4. Average values and analysis of variance for weed density and weed above-ground biomass of weedy plots under different cultivars and fertilization treatments

\begin{tabular}{|c|c|c|c|c|c|c|c|}
\hline \multirow[b]{2}{*}{ Cultivar } & \multirow[b]{2}{*}{ Fertilization } & \multicolumn{3}{|c|}{ Annual weeds } & \multicolumn{3}{|c|}{ Perennial weeds } \\
\hline & & A. retroflexus & E. crus-galli & P. oreracea & M. sylvestris & S. elaeagnifolium & C. arvensis \\
\hline & & \multicolumn{6}{|c|}{ Weed density (number $\mathrm{m}^{-2}$ ) } \\
\hline \multirow[t]{4}{*}{ 'Uso 31' } & $0 \mathrm{~N}$ & 6 & 8 & 0 & 4 & 182 & 8 \\
\hline & $70 \mathrm{~N}$ & 10 & 26 & 0 & 8 & 210 & 36 \\
\hline & $140 \mathrm{~N}$ & 26 & 36 & 98 & 58 & 114 & 0 \\
\hline & Mean & 14 & 23.3 & 32.7 & 23.3 & 168.7 & 14.7 \\
\hline \multirow[t]{4}{*}{ 'Fedora 17' } & $0 \mathrm{~N}$ & 16 & 8 & 6 & 18 & 204 & 12 \\
\hline & $70 \mathrm{~N}$ & 16 & 16 & 0 & 0 & 234 & 0 \\
\hline & $140 \mathrm{~N}$ & 0 & 18 & 24 & 2 & 84 & 0 \\
\hline & Mean & 10,7 & 14 & 10 & 6.67 & 174 & 4 \\
\hline \multirow[t]{6}{*}{ 'Futura 75’ } & $0 \mathrm{~N}$ & 12 & 4 & 2 & 4 & 82 & 6 \\
\hline & $70 \mathrm{~N}$ & 14 & 22 & 2 & 0 & 148 & 10 \\
\hline & $140 \mathrm{~N}$ & 2 & 52 & 22 & 94 & 216 & 0 \\
\hline & Mean & 9,33 & 26 & 8.67 & 32.7 & 148.7 & 5.33 \\
\hline & $\mathrm{LSD}_{\mathrm{C} \times \mathrm{F}(0.05)}$ & 3.30 & 8.53 & 7.36 & 17.7 & 17.8 & 2.59 \\
\hline & $\mathrm{LSD}_{\mathrm{C} \times \mathrm{W}(0.05)}$ & 3.29 & 6.18 & 8.69 & 18.7 & 30.6 & 3.38 \\
\hline $\mathrm{C}$ & & ns & $* *$ & * & ns & ns & * \\
\hline $\mathrm{F}$ & & ns & $* * *$ & $* * *$ & $* * *$ & $* * *$ & $* * *$ \\
\hline $\mathrm{C} \times \mathrm{F}$ & & $* * *$ & $*$ & $* * *$ & $* *$ & $* * *$ & $* * *$ \\
\hline $\mathrm{W}$ & & $* * *$ & *** & $* * *$ & $* * *$ & $* * *$ & $* * *$ \\
\hline $\mathrm{C} \times \mathrm{W}$ & & $*$ & $*$ & $* * *$ & * & ns & $* * *$ \\
\hline $\mathrm{F} \times \mathrm{W}$ & & ns & $* * *$ & $* * *$ & $* * *$ & ** & $* * *$ \\
\hline \multirow{2}{*}{$\mathrm{C} \times \mathrm{F} \times \mathrm{W}$} & & $* * *$ & $* *$ & $* * *$ & $* *$ & $* * *$ & $* * *$ \\
\hline & & \multicolumn{6}{|c|}{ Weed above-ground biomass $\left(\mathrm{g} \mathrm{m}^{-2}\right)$} \\
\hline \multirow[t]{4}{*}{ 'Uso 31’' } & $0 \mathrm{~N}$ & 20.4 & 34.8 & 0 & 3.78 & 82.3 & 9.82 \\
\hline & $70 \mathrm{~N}$ & 17.4 & 31.0 & 0 & 3.86 & 71.1 & 14.0 \\
\hline & $140 \mathrm{~N}$ & 11.4 & 22.5 & 131.9 & 20.7 & 50.9 & 0 \\
\hline & Mean & 16.4 & 29.4 & 44 & 9.46 & 68.1 & 7.94 \\
\hline \multirow[t]{4}{*}{ 'Fedora 17' } & $0 \mathrm{~N}$ & 10.1 & 1.60 & 5.20 & 11.0 & 100.8 & 1.68 \\
\hline & $70 \mathrm{~N}$ & 6.68 & 49.2 & 0 & 0 & 27.9 & 0 \\
\hline & $140 \mathrm{~N}$ & 0 & 21.7 & 57.1 & 6.84 & 24.8 & 0 \\
\hline & Mean & 5.59 & 24.2 & 20.8 & 5.95 & 51.2 & 0.56 \\
\hline \multirow[t]{6}{*}{ 'Futura 75' } & $0 \mathrm{~N}$ & 10.6 & 1.84 & 3.20 & 4.64 & 36.1 & 3.78 \\
\hline & $70 \mathrm{~N}$ & 11.0 & 27.6 & 1.92 & 0 & 71.1 & 4.18 \\
\hline & $140 \mathrm{~N}$ & 2.40 & 57.0 & 15.5 & 36.3 & 61.7 & 0 \\
\hline & Mean & 7.99 & 28.8 & 6.87 & 13.7 & 56.3 & 2.65 \\
\hline & $\operatorname{LSD}_{\mathrm{C} \times \mathrm{F}(0.05)}$ & 2.31 & 13.5 & 22 & 8.04 & 17.1 & 1 \\
\hline & $\mathrm{LSD}_{\mathrm{C} \times \mathrm{W}(0.05)}$ & 6.03 & 13.2 & 24.3 & 9.71 & 18.6 & 0.77 \\
\hline $\mathrm{C}$ & & ns & ns & ns & ns & ns & $* * *$ \\
\hline $\mathrm{F}$ & & $* * *$ & $*$ & $* * *$ & $* *$ & * & $* * *$ \\
\hline $\mathrm{C} \times \mathrm{F}$ & & $*$ & $* *$ & $* *$ & * & $* *$ & $* * *$ \\
\hline $\mathrm{W}$ & & $* * *$ & $* * *$ & $* * *$ & $* * *$ & $* * *$ & $* * *$ \\
\hline $\mathrm{C} \times \mathrm{W}$ & & $* *$ & ns & * & ns & ns & $* * *$ \\
\hline $\mathrm{F} \times \mathrm{W}$ & & $* *$ & $* *$ & $* * *$ & $* *$ & * & $* * *$ \\
\hline $\mathrm{C} \times \mathrm{F} \times \mathrm{W}$ & & ns & $* *$ & $* *$ & * & $* *$ & $* * *$ \\
\hline
\end{tabular}

Note: $\mathrm{C}=$ cultivars, $\mathrm{F}=$ fertilization treatments [control $\left.(0 \mathrm{~N}), 70 \mathrm{~kg} \mathrm{ha}^{-1}(70 \mathrm{~N}), 140 \mathrm{~kg} \mathrm{ha}^{-1}(140 \mathrm{~N})\right], \mathrm{W}=$ weed management, ns = not significant; significant at ${ }^{*} P<0.05,{ }^{* *} P<0.01,{ }^{* * *} P<0.001$. LSD test, $P<0.05$. 
particular, weed density of E. crus-galli, P. oleracea, $M$. sylvestris and A. retroflexus increased from 56 to $100 \%$ at the high $\mathrm{N}$ dose compared with the control in the majority of the cultivar plots. On the contrary, weeds like $S$. elaeagnifolium and $C$. arvensis showed different response (Tab. 4).

Similar results were observed in the majority of cases for weed biomass especially in $P$. oleracea and M. sylvestris (increase from 79 to $100 \%$ ), indicating that the specific weeds may be highly competitive at high levels of nitrogen application. Nutrients and primary nitrogen (N) may influence diversity, abundance and growth of weeds. Depending on weed species and density, N fertilization can increase the competitive ability of weeds more than that of the crop, leading to little or no increase in crop yield (Blacksaw et al., 2003, Sweeney et al., 2008; Travlos et al., 2018). Previous researches have revealed that nitrogen addition increased, decreased or had little effects on weed competitive ability, which might be crop and weed specific, as a result of inherent variations in responsiveness to soil $\mathrm{N}$ levels (Cathcart and Swanton, 2003; Abouziena et al., 2007; Blackshaw and Brandt, 2008; Travlos et al., 2019). Moreover, our results are in agreement with the findings of other studies reporting that some weeds such as $A$. retroflexus, E. crus-galli, P. oleracea and $M$. sylvestris showed higher competitiveness at high nitrogen availability and consequently they could be characterized as nitrophilous (Blackshaw et al., 2003; Abouziena et al., 2007).

\section{Conclusion}

The results of the present study confirm that nitrogen fertilization might have an impact on the weed competitive ability. In addition, hemp cultivars showed different efficiency of weed suppression especially in the early growth stage. The increased values of the measured crop traits especially in the $140 \mathrm{~N}$ treatments might be due to the fact that weeding facilitated the crop for better absorption of nutrients, moisture and solar radiation for higher yield. Therefore, hemp should be kept free of weeds in early crop development, especially at low densities, where the weed competition is higher. Further research is needed in order to access useful information on interactions between weeds and hemp crop to address potential yield losses under different cultural practices and weed management systems.

\section{References}

1. Abouziena HF, El-Karmany MF, Singh M, Sharma SD (2007). Effect of nitrogen rates and weed control treatments on maize yield and associated weeds in sandy soils. Weed Technol., 21: 1049-1053.

2. Amaducci S, Scordia D, Liu FH, Zhang Q, Guo H, Testa G, Cosentino SL (2015). Key cultivation techniques for hemp in Europe and China. Ind. Crops Prod., 68: 2-16.

3. Aubin MP, Seguin P, Vanasse A, Tremblay GF, Mustafa AF, Charron JB (2015). Industrial Hemp Response to Nitrogen, Phosphorus, and Potassium Fertilization. Crop, Forage Turfgrass Manag., 1: 1-10.

4. Bilalis D, Karidogianni S, Roussis I, Kouneli V, Kakabouki I, Folina A (2019). Cannabis sativa L.: A new promising crop for medical and industrial use. Bulletin UASVM Horticulture, 76(2): 145-150.

5. Blackshaw RE, Brandt RN, Janzen HH, Entz T, Grant CA, Derksen DA (2003). Differential response of weed species to added nitrogen. Weed Sci., 51: 532-539.

6. Blackshaw RE, Brandt RN (2008). Nitrogen fertilizer rate effects on weed competitiveness is species dependent. Weed Sci., 56: 743-747.

7. Campiglia E, Radicetti E, Mancinelli R (2017). Plant density and nitrogen fertilization affect agronomic performance of industrial hemp (Cannabis sativa L.) in Mediterranean environment. Ind. Crops Prod., 100: 246-254.

8. Carus M (2017). The European Hemp Industry: cultivation, processing and applications for fibres, shives, seeds and flowers. European Industrial Hemp Association, 2017/03.

9. Cathcart RJ, Chandler K, Swanton CJ (2004). Fertilizer nitrogen rate and the response of weeds to herbicides. Weed Sci., 52(2): 291-296.

10. Deng G, Du G, Yang Y, Bao Y, Liu F (2019) Planting density and fertilization evidently influence the fiber yield of hemp (Cannabis sativa L.). Agronomy, 9(7): 368.

11. FAOSTAT (2018). Food and Agricultural Organization of the United Nations. Statistics Database.

12. Flessner M, Bryd J, Bamber K, Fike J (2020). Evaluating herbicide tolerance of industrial hemp (Cannabis sativa L.). Crop Sci., 60: 419-427.

13. Hall J, Bhattarai SP, Midmore DJ (2014). Effect of industrial hemp (Cannabis sativa L.) planting density on weed suppression, crop growth, physiological responses and fibre yield in the subtropics. Renew. Bioresour., 2: 1.

14. Jankauskiené Z, Gruzdeviené E, Lazauskas S (2014). Potential of industrial hemp (Cannabis sativa L.) genotypes to suppress weeds. Zemdirbyste, 101(3): 265-270.

15. Papastylianou P, Kakabouki I, Travlos I (2018). Effect of nitrogen fertilization on growth and yield of industrial hemp (Cannabis sativa L.). Not. Bot. Horti. Agrobot., 46(1): 197-201.

16. Pudelko K, Majchrzak L, Narozna D (2014). Allelopathic effect of fibre hemp (Cannabis sativa L.) on monocot and dicot plant species. Ind Crops Prod., 56: 191-199.

17. Salentijn EMJ, Zhang Q Amaducci S, Yang M, Trindade LM (2015). New developments in fiber hemp (Cannabis sativa L.) breeding. Ind. Crops Prod., 68: 32-41. 
18. Sandler LN, Gibson KA (2019). A call for weed research in industrial hemp (Cannabis sativa L.). Weed Res., 59: 255259.

19. Sausserde R, Adamovičs A, Ivanovs S, Bulgakov V (2013). Investigations into growing and harvesting industrial hemp. J. Res. Appl. Agric. Engng., 58(4): 150-154.

20. Struik PC, Amaducci S, Bullard MJ, Stutterheim NC, Venturi G, Cromack HTH (2000). Agronomy of fibre hemp (Cannabis sativa L.) in Europe. Ind. Crops Prod., 11: 107118.

21. Sweeney AE, Renner KA, Laboski C, Davis A (2008). Effect of fertilizer nitrogen on weed emergence and growth. Weed Sci., 56: 714-721.
22. Tang K, Struik PC, Yin X, Thoumicot C, Bjelková $\mathrm{M}$, Stramkale V, Amaducci S (2016). Comparing hemp (Cannabis sativa L.) cultivars for dual-purpose production under contrasting environments. Ind. Crops Prod., 87: 3344.

23. Travlos I, Cheimona N, Roussi I, Bilalis D (2018). Weedspecies abundance and diversity indices in relation to tillage systems and fertilization. Front. Environ. Sci. 6: 11.

24. Travlos I, Papastylianou P, Alexos A, Kanatas P, Bilalis D, Tsekoura A, Kakabouki I, Cheimona N (2019). Changes of weed flora due to nitrogen addition in sunflower. Not. Bot. Horti. Agrobot., 47(4): 1337-1339. 